\title{
Quality Assesment of Pepper Paste Using Different Milling Methods
}

\author{
Bankole, Y.O. ${ }^{1}$ \\ Taninola, O.A. ${ }^{1}$ \\ Adesina, B.S. ${ }^{1}$ \\ Samuel, D.O. ${ }^{2}$ \\ ${ }^{1}$ Department of Agricultural \& Bio-Environmental Engineering, \\ Lagos State Polytechnic, Ikorodu-Nigeria \\ ${ }^{2}$ Department of Food Technology, School of Technology, \\ Lagos State Polytechnic, Ikorodu-Nigeria
}

\section{Doi:10.5901/ ajis.2013.v2n10p187}

\begin{abstract}
This paper focused on milling methods for pepper. Four milling methods were considered; Attrition, Stone, Mortar \& pestle, and Blender. Investigation on the quality; the microbial analysis, the physiochemical analysis, and the sensory evaluation were carried out on pepper milled using these milling methods mention above. The output temperature of the pepper for stone, mortar \& pestle, blender and attrition were 38.470C, 38.470C, 48.370C and $48.470 \mathrm{C}$ respectively. The yield efficiency of the pepper for Attrition, mortar \& pestle and Blender were $87.1 \%, 90.47 \%, 94.4 \%$ and $96.17 \%$ respectively. Total plate count, coliform count and fungal count for Attrition, Stone, mortar \& pestle and Blender were $1.6 \times 10-6,2.3 \times 102 \& 8 \times 10-5 ; 1.65 \times 10-5,1.29 \times 102 \&$ $2.08 \times 10-3 ; 7.4 \times 10-6,4.9 \times 10-3 \& 1 \times 10-3 ;$ and $2.28 \times 10-9,1.33 \times 102 \& 2.16 \times 10-3$ respectively. Showing that Attrition had the highest level of microbiological contamination. Physiochemical analysis of the product for Attrition had reduction in protein, ester extract, (fat), ash and crude fibre. It also has high level of iron, zinc, and magnesium compared to the other methods of milling, these show that the nutrient contents of the product was adversely affected. Sensory evaluation shows that the colour and texture of the pepper milled with Attrition and stone were preferred above mortar \& pestle and blender. In terms of quality, stone and Mortar \& pestle have advantage over Attrition and blender, with the nutrients having little or no significant damage with less microbial contamination.
\end{abstract}

Keywords: Quality, Pepper, Milling,Methods, Assesments

\section{I ntroduction}

Pepper is often described as the king of spices and it shares a place on most dinner tables with salt. The word pepper originated from the Sanskrit word "pippali", meaning berry. It is grown almost every part of the world today. It also comes in different sizes, colors and shapes. The colors can either be white, black, red or green (Azghar Ali Farooqi et al., 2005).

Pepper as other vegetables serves as a good source of antioxidant substances such as caroteniods (provitamin A) and vitamin $\mathrm{C}$ which confer protection against carcinogenic components and delay aging process. It is also rich in ascorbic acid and other phytochemicals. Red pepper is sensitive to aflatoxin contaminations depending on the atmospheric temperature, humidity, drying and processing conditions.

Traditionally, pepper is processed either in its fresh form or dry state. In the ancient times pepper is mostly milled using stone mill or mortar with pestle. With the introduction of technology, other forms of milling methods are now being introduced. Despite the introduction of new, easy 
and contamination - free milling methods, many people still prefer the ancient and local ways of milling pepper claiming that it is more nutritional than the ones milled using the new technology.

The major components of the soluble neutral sugars found in pepper fruit are sucrose, glucose and fructose which is responsible for its sweetness (Luning et al. 1994). Fructose and glucose constituted the known fermentable sugars in beans, cucumbers and pepper (both in green and red pepper) (Nielson et al., 1991).

The most apparent changes in term of composition and size occur in the pectic fraction of the cell wall, which include increased solubility, depolyinerization, de esterification and a significant net loss of neutral sugar-containing side chains.( Fisher and Bennett, 1991; Seymour and Gross, 1996). Arancibia (2003) suggested that disruption side chains of the cell wall structure and separation of cellular components by grinding with $100 \%$ alcohol facilitated the released of soluble pectin. He concluded that pectin content remained the same throughout the ripening process which ranged between $78 \mu \mathrm{g} / \mathrm{mg}$ to $104 \mu \mathrm{g} / \mathrm{mg}$ with an average of $88 \mu \mathrm{g} / \mathrm{mg}$.

Pungency in pepper is due to the amount of capsaicinoids, including capsaicin and four structurally related compounds namely nordihydrocapsaicin, dihydrocapsaicin, homocapsaisin and homodihydrocapsaicin (Hoffman et al., 1983). These are alkaloid compounds that produce the hot flavor or pungency associated with eating chili (Collins et al. 1995). Pungency is the most outstanding property of capsicums, resulting from the direct effect of capsaicin. Capsaicin content, as determined by the method outlined by Bajaj (1980).

Deshpande et al. (1982) reported that phosphate in plant is stored in seeds as phytate and is present in the outer aleurone layer of the cotyledons of the endosperm. Phytate affects the nutrient availability and reduces protein quality. Phytate also interact with protein and reduces protein solubility and availability (Sathe and Salunkhe, 1984). .

Polyphenolic compounds adversely affect protein digestibility and may inhibit hydrolytic enzymes such as $\alpha$-amylase. Polyphenols also impart intense colour and off flavours.( Deshpande and Damodaran, 1990; Sathe and Salunkhe, 1984).

Many food processes frequently require the reduction in size of solid materials for different purposes.eg. Size reduction may aid other process such as expression and extraction or may shorten heat treatment, as in blanching and cooking. Comminution is the generic term used for size reduction and includes different operation such as crushing, grinding and milling, mincing and dicing. Most of these terms are related to a particular application. The reduction mechanism deforms the pieces of food until it breaks or tears. Breaking of hard material along cracks or deflects in their structure is achieved by applying diverse forces. The types of forces commonly used in food processes are compressive, impact, attrition or shear and cutting (Brennau et al., 1981).

It is also accepted that only a small percentage of energy supplied to the grinding equipment is actually used in the breakdown operations. Much of the input energy is lost in deforming the particles within their elastic limits and through inter-particle friction. A large amount of this wasted energy is released as heat, which in turn may be responsible for heat damages of biological material.

Milling is a unit operation designed to break a solid material into smaller pieces (Mc Gee 2004). It is also used to create a free-flowing material. Milling usually involves constraints with regard to particle size. Particles size is controlled by using different screens and clearances. The type of mill used also has a major impact on quality yield of the output. Milling is divided into wet and dry milling. Wet milling is used on produce to produce fiber starch and protein extracts. Kethireddipalli et al. (2002) reported that freshly wet milled paste produces dishes of superior quality. Overall wet milling produced a superior taste and end product.

Milling involves the application of external force; the amount of particles reduction caused by the external forces depends on the amount of energy applied to the particle, the rate at which it is applied (Wennerstrum et al., 2002). 


\section{Materials and Methodology}

Sixty grammes of pepper were milled, using Attrition, Stone, Mortar \& pestle, and Blender. The following parameters were measured during the milling process: time taken to mill and temperature. Sensory evaluations, such as texture and colour were carried out by setting up panelists. Microbial analysis (total plate count and coliform count) was carried out on each of the output. Nutritional analyses were also carried out. The output/yield percentage was calculated using the expression below

$$
\text { yeild } \%=\frac{\text { output }}{\text { input }} \times 100 \text { (1) }
$$

The through put value was also determined using the expression below according to Kethireddipalli et al., (2002.)

$$
\text { Throughput }=\frac{\text { mass of input }}{\text { time }}(\mathrm{kg} / \mathrm{min})(2)
$$

Measured parameters of the chemical analyses of the milled samples from the different milling methods include alkalinity, acidity, chloride and hardness using standard methods. The amount of iron and magnesium present were measured using the method described by Olutiola et al. (1991).

Proximate analysis was also carried out. The following parameters were measured: moisture content, ash content, crude fat, protein, crude fibre, carbohydrate and vitamin C using standard methods. Sensory evaluation was also carried out using the 9 - point Hedonic scale

\section{Results and Discussion}

The mean values of the milling parameters is presented in Table 1.

Table 1. Mean parameters of milling methods

\begin{tabular}{lcccc}
\hline \multicolumn{1}{c}{$\mathrm{S} / \mathrm{N}$} & Attrition milling & Stone milling & Mortar and pestle & Blender \\
\hline Milling time $(\min )$ & $6.87( \pm 0.25)$ & $13.17( \pm 0.37)$ & $14.77( \pm 0.38)$ & $6.27( \pm 0.15)$ \\
Temperature $\left({ }^{0} \mathrm{C}\right)$ & $48.47( \pm 0.25)$ & $38.47( \pm 0.06)$ & $38.47( \pm 0.06)$ & $42.37( \pm 0.06)$ \\
Yield \% & $87.1( \pm 0.3)$ & $90.47( \pm 0.21)$ & $94.4( \pm 0.3)$ & $96.17( \pm 0.15)$ \\
Throughput $(\mathrm{kg} / \mathrm{min})$ & $8.76( \pm 0.33)$ & $4.6( \pm 0.12)$ & $4.07( \pm 0.11)$ & $9.59( \pm 0.24)$ \\
\hline
\end{tabular}

The standard deviations are in parenthesis.

The results on the microbial analysis of the different milling methods are as shown in Table 2.

\begin{tabular}{|c|c|c|c|c|}
\hline & Attrition milling & Stone milling & Mortar and pestle & Blender \\
\hline $\begin{array}{l}\text { Total viable count } \\
\text { (cfus/g) }\end{array}$ & 5333 & 5600 & 2467 & 7600 \\
\hline Organism isolated & $\begin{array}{l}\text { Bacillus spp; } \\
\text { Pseudomonas sp; } \\
\text { Flavobacterium sp }\end{array}$ & $\begin{array}{c}\text { Bacillus spp; } \\
\text { Pseudomonas sp; } \\
\text { Flavobacterium sp }\end{array}$ & $\begin{array}{c}\text { Bacillus spp; } \\
\text { Pseudomonas sp; }\end{array}$ & $\begin{array}{c}\text { Bacillus spp; } \\
\text { Pseudomonas sp; }\end{array}$ \\
\hline $\begin{array}{l}\text { Total coliform } \\
\text { count (cfus/g) }\end{array}$ & 7667 & 4300 & 1633 & 4433 \\
\hline Organism isolated & $\begin{array}{c}\text { Aeromonas sp; } \\
\text { Enterobacterium sp }\end{array}$ & Aeromonas sp; & Aeromonas sp; & Aeromonas sp; \\
\hline $\begin{array}{l}\text { Total plate count } \\
\text { (cfus/g) }\end{array}$ & 2667 & 6933 & 3333 & 7200 \\
\hline Organism isolated & $\begin{array}{l}\text { Aspergillus spp; } \\
\text { Rhizopus sp }\end{array}$ & $\begin{array}{c}\text { Aspergillus spp; } \\
\text { Rhizopus }\end{array}$ & Aspergillus sp; & $\begin{array}{c}\text { Aspergillus } \\
\text { spp; Rhizopus sp }\end{array}$ \\
\hline
\end{tabular}

Table 2. Mean value of Microbial analysis 
The physiochemical properties of the milled pepper using the four different milling methods are presented in Table 3.

Table 3. Mean values of physiochemical parameters

\begin{tabular}{|c|c|c|c|c|}
\hline Parameters & Attrition milling & Stone milling & Mortar and pestle & Blender \\
\hline Moisture content (\%) & $87.23( \pm 0.12)$ & $86.73( \pm 0.15)$ & $84.37( \pm 0.15)$ & $85.73( \pm 0.15)$ \\
\hline Protein (\%) & $1.3( \pm 0.1)$ & $1.47( \pm 0.06)$ & $1.63( \pm 0.06)$ & $1.57( \pm 1.14)$ \\
\hline Ether extract (fat) \% & $0.47( \pm 0.06)$ & $0.53( \pm 0.06)$ & $0.57( \pm 0.06)$ & $0.53( \pm 0.06)$ \\
\hline Ash (\%) & $2.83( \pm 0.12)$ & $3.1(0)$ & $3.1( \pm 0.51)$ & $3.07( \pm 0.06)$ \\
\hline Crude fibre & $2.17( \pm 0.15)$ & $2.4(0)$ & $=0.1)$ & $2.33( \pm 0.06)$ \\
\hline $\begin{array}{l}\text { Carbohydrates (by } \\
\text { difference) } \%\end{array}$ & $6( \pm 0.17)$ & $5.73( \pm 0.15)$ & $7.93( \pm 0.06)$ & $6.77( \pm 0.06)$ \\
\hline $\mathrm{Ca}^{++}(\mathrm{mg} / 100 \mathrm{~g})$ & $65(0)$ & $66.33( \pm 0.57)$ & $66.67( \pm 0.58)$ & $65.33( \pm 0.58)$ \\
\hline $\mathrm{Fe}^{++}(\mathrm{mg} / 100 \mathrm{~g})$ & $4.87( \pm 0.12)$ & $2.97( \pm 0.06)$ & $2.13( \pm 0.06)$ & $2.4( \pm 0.1)$ \\
\hline $\mathrm{Zn}^{++}(\mathrm{mg} / 100 \mathrm{~g})$ & $0.67( \pm 0.06)$ & $0.4(0)$ & $0.3(0)$ & $0.43( \pm 0.06)$ \\
\hline $\mathrm{Mg}^{++}(\mathrm{mg} / 100 \mathrm{~g})$ & $1.53( \pm 0.06)$ & $1.2(0)$ & $1.3(0)$ & $1.3( \pm 0.1)$ \\
\hline $\mathrm{PO}_{4}{ }^{--}(\mathrm{mg} / 100 \mathrm{~g})$ & $85(0)$ & $86.67( \pm 5.77)$ & $90( \pm 5)$ & $90(0)$ \\
\hline $\begin{array}{l}\text { Ascorbic acid } \\
(\mathrm{mg} / 100 \mathrm{~g})\end{array}$ & $35.23( \pm 0.25)$ & $45.23( \pm 0.25)$ & $35.23( \pm 0.2)$ & $45.13( \pm 0.12)$ \\
\hline Foaming capacity (\%) & $13.03( \pm 0.21)$ & $13.83( \pm 0.80)$ & $13.83( \pm 0.15)$ & $13.3( \pm 0.17)$ \\
\hline Foam stability (\%) & 0 & 0 & 0 & 0 \\
\hline Total titratable acidity & $0.89( \pm 0.01)$ & $0.86( \pm 0.01)$ & $0.83(0)$ & $0.86( \pm 0.01)$ \\
\hline
\end{tabular}

The standard deviations are in parenthesis.

Table 4 shows mean values of sensory evaluation carried out for the different milling methods

Table 4. Mean value for sensory evaluation

\begin{tabular}{lll}
\hline \multicolumn{1}{c}{ Milling methods } & \multicolumn{1}{c}{ Colour } & \multicolumn{1}{c}{ Texture } \\
\hline Attrition milling & Very much dislike & Moderately like \\
Stone milling & Very much dislike & Moderately like \\
Mortar and pestle & Moderately dislike & Very much dislike \\
Blender & Slightly like & Neither like or dislike \\
\hline
\end{tabular}

\section{Discussions}

During the milling processes, it was observed that it took a longer time using stone, and the mortar and pestle but the output's temperature was low. Attrition milling and blender took a shorter period but the temperature of the output was high. It was noted that the milling time for mortar and pestle also depends on human factor; this is because it requires high energy. The miller stops milling as soon as he gets tired. But it's less stressful when compared to stone milling. Table 1 shows the difference in the milling time of the four milling methods used. The milling time for mortar was found to be highest and despite the time being used, its output remains coarse unlike that of attrition milling and blender which takes a shorter time to mill but still has a smooth texture when compared to mortar and pestle.

High temperature is said to reduce some nutrients like protein and dietary fibre in foods. After milling, it was observed that the temperature of the product from the different milling methods varies. The exit temperature of the product from Attrition milling and Blender was observed to be higher while that of Stone mill and Mortar were low (Table 1).

There was a decrease in the output of pepper when using attrition mill; this was because most of the pepper got stuck in the mill discs of the machine. There was a greater yield percentage 
in the product milled from Blender when compared to the other three methods. The yield percentage from stone is also high but there were some losses and this was as a result of the surface of the stone used in milling.

In terms of texture, attrition milling is the smoothest and that of stone milling is also smooth but this was obtained after repeated milling. The texture of output from blender and, mortar and pestle is coarse. A panelist was set up and it was observed that most of them preferred the texture from attrition mill. In terms of colour, the product from attrition mill was found to be different when compared to others. When the products were observed, it was noted that the product from Attrition milling had a dark red colour, this was as a result of the material used for constructing the machine, and the grease used for lubricating the moving parts.

The outputs, when subjected to physiochemical analysis, it was observed that there was a significant decrease in the protein, fat and fibre contents of the product from attrition mill. This was as a result of the high temperature recorded from the use of the machine. It was also observed that there was an increase in the iron and zinc content; this was as a result of the material used for constructing the machine. During the milling process, the movement of the rotating parts causes tiny chips of metal to get into the food. When this happens, there is a chemical reaction between the food and the chips that falls in them. This can be harmful to the human health. It was also observed that the milled food from Attrition mill was very acidic when compared to the other milling methods. Acidity of the food is said to be as a result of the chemical reactions that took place in the food. It was observed that Mortar and pestle had the highest amount of carbohydrates.

Microbial analysis carried out as presented in Tables 2 shows that, there was a large amount of fungi found in the product from Attrition milling. The microbial load or contamination was found to be lowest in the product from Mortar and pestle. The contamination load in the product from Attrition mill was as a result of hide outs found in the machine.

Contamination from mortar and stone depends on the hygiene of the user. It was observed that when a hole appears on the surface of the stone where food is milled, the continuous rubbing of the grinding stone against the stone's surface automatically smoothen the surface. It was also observed that the position of the person milling with stone matters a lot. The miller should be in a squatting position and must not bend over the stone, thereby preventing sweat from getting in contact with the food. It was also observed that the wood for the construction of Mortar affects the quality of the product.

\section{Conclusion}

Every consumer of food has preference on what type of processing technique to use. From the analysis done, it was discovered that stone and Mortar had minimal disadvantages. Most or if not all the nutrients in pepper are kept intact, with little or no significant damage. The use of these milling method; stone and Mortar is the best because the product can still retain its quality in order to provide the body with the necessary requirement. Most people use Attrition mill every day without knowing the implication it has on their health.

It can be concluded that the quality of pepper can still be kept undestroyed when the right milling method is used. The pepper milled on stone and mortar is of a better quality than that of blender and attrition mill, but it is time consuming and requires a great deal of labour. Commercially, the use of stone mill or mortar to mill a large quantity of pepper can be discouraging. But attrition mill can mill a larger quantity of pepper at a shorter time.

\section{Recommendations}

From the results, it was discovered that the pepper paste from stone mill was of a high quality when compared to the other methods used. But the use of stone is an ancient and outdated way of 
milling pepper. It is time consuming and strenuous. Therefore, the following were recommended;

1. That attrition mill should be constructed using stainless steel material.

2. The amount of water to be used during the milling process should be specified. This will help to reduce the amount of soluble protein that will be washed away.

3. Because of the rapid growth in technology, the limestone used in stone milling can be used in constructing the grinding part of the attrition mill. This can be achieved by cutting the stone into disc and then attached to attrition mill or a plate mill. Its operations are essentially the same in that mechanical shearing and compression on the material are the main grinding forces.

\section{References}

Arancibia, R. A. (2003). Enhanced Pectin Degradation is Associated with the Ease of Fruit Detachment in Tabasco Pepper. Phd Dissertation. Louisiana State University.

Azghar Ali Farooqi, Sreeremu. B.S., and Srinivasappa K.N (2005). Cultivation of spice crops. University press. Pp. 336

Bajaj, K. L. (1980). Colorimetric determination of capsaicin in Capsicum fruits. J. Assoc. Offic. Anal. Chem. 63(6): 1314-1316.

Brennau J.G, Butters. J.R, Cowell .N.D. and Lilly. A.V.E. (1981). Food engineering operations, 2nd edition reprinted. Applied science publishers

Collins, M.D., Wasmund, L.M., and Bosland, P.W. (1995). Improved method for

quantifying capsaicinoids in capsicum using high performance liquid

chromatography. HortScience 30(1):137-139.

Dashpande, S.S., Sathe, S.K., Salunke, D.K. and Comfort, D.P.(1982). Effects of dehulling on phytic acid, polyphenols and enzymes inhibitors of dry beans (Phaseolus Vulgaris L) J. food science 47, 1846-1850

Deshpande, S.S. and Damodaran, S. (1990). Food legumes: chemistry and technology. In Advances in Cereal Sci. and Technology (Vol. X) (Y. Pomeranz, ed.). St.Paul, MN: American Association of Cereal Chemists, Inc. Pp. 147-241.

Fisher, R. L. and Bennett, A. B. (1991). Role of cell wall hydrolases in fruit ripening. Annu. Rev. Plant Physiol. Plant Mol. Biol. 42: 675-703.

Gbile .Z.O. (1984). Vernacular names of Nigerian Plants (Yoruba). Forestry research Institute of Nigeria. Ibadan

Hoffman, P.G., M.C. Lego, and W.G. Galetto. (1983). Separation and quantification of red pepper major heat principles by reverse-phase high pressure liquid chromatography. J. Agr. Food Chem. 31: 1326-1330.

Kethireddipalli. P, Hung. Y.C, Mc Watters K.H and Phillips .R.D. (2002a). Effect of milling method (wet and dry) on the functional properties of cowpea (vigna unguiculata) pastes and end product quality. Journal of food science 67(1): 48-52.

Luning P. A., Vries R. V., Yuksei D., Ebberhorst-Seller T., Wichers H. J, and Roozen J.P. (1994). Combined instrumental and sensory evaluation of flavor of fresh bell peppers (Capsisum annuum) harvested at three maturation stages. J. Agric. Food Chem. 42, 2885-2861

Mc Gee .H.(2004). On food and cooking. TheScience and love of the kitchen. Complementary revised and updated edition. New York Scribber xi, 884P.

Nielson, T. H., Skjaerbaek H. C., and Karlsen P. (1991) Carbohydrate metabolism during fruit development in sweet pepper (Capsicum annuum) plants. Physiologia planetarium 82: 311-319

Olutiola, P.O., Famurewa, O. and Sonntag, H.G. (1991). An Introduction to General Microbiology. A Practical Approach. Heidelberger Verlagsanstalt und Druckerei $\mathrm{GmbH}$, Heidelberg. Federal Republic of Germany. Pp. 60 - 62, $124-127,165-166,177-178$.

Sathe, S.K. and Salunkhe, D.K. (1984). Technology and removal of unwanted

components of beans. CRC Crit. Rev. Food Sci. Nutr. 21(3). 263-287.

Seymour, G.B. and Gross, K.C (1996). Cell wall disassembly and fruit softening, postharvest news and information 7, 5N-52N.

Wennerstrum. S, Kendrick. T, Tomaka. J and Cain. J. (2002). Powder and bulk Engineering ; size reduction solutions for hard-to-reduce materials (the Fitzpatrick co). 